\title{
Viranhaltijoiden suhtautuminen kuntalaisosallistumisen lisäämiseen kuntahallinnossa
}

\author{
Mikko Värttö \& Lauri Rapeli
}

\begin{abstract}
"Public administrators' perceptions of public engagement in local government"

This article is an empirical study of the attitudes of public administrators toward public engagement. Currently there is a gap in the research on the attitudes of senior public servants who are important gate-keepers for the implementation of public engagement policies. This article contributes to filling this gap in the research by using interviews with senior public servants in a Finnish municipality. The study reveals that the administrators positively value citizens and their participation. However, there are differing views concerning the relationships between the new models of civic participation and the traditional models of planning and decision-making. The results indicate that there is an ongoing cultural change within the administration. The main factors that undermine the realization of public engagement policy can be divided into legislative, organizational, individual and cultural capacities.
\end{abstract}

Keywords: Public engagement, local government

\section{JOHDANTO}

Kuntalaisten osallistumismahdollisuuksien kehittäminen on noussut ajankohtaiseksi teemaksi monissa Suomen kunnissa. Kuntalaisten osallistumismahdollisuuksien edistämistä perustellaan tarpeella vastata julkisessa päätöksenteossa vallitsevaan "demokratiavajeeseen", joka näkyy muun muassa poliittisiin instituutioihin kohdistuvan luottamuksen heikentymisenä, poliittisen kiinnittyneisyyden vähentymisenä sekä äänestysaktiivisuuden laskemisena (Borg 2013,
17; Sjöblom 2011, 251). Tarjoamalla kansalaisille vaihtoehtoisia tapoja osallistua päätösten valmisteluun sekä päätöksentekoon voidaan lisätä kansalaisten osallistumisaktiivisuutta sekä vahvistaa poliittisen järjestelmän legitimiteettiä (Michels \& Graaf 2010; Bherer 2010).

Viime vuosien aikana monet kunnat ovat koonneet ja kirjanneet osallistumisen toteuttamistavoitteet ja -tavat kunnan strategisiin asiakirjoihin ja ohjelmiin. Suurista kunnista esimerkiksi Helsinki, Oulu ja Rovaniemi ovat esitelleet uuden osallisuusmallinsa. Osallisuusmalleilla viitataan paikallishallinnon virallisiin osallistumistavoitteisiin sekä niiden saavuttamiseen tähtääviin toimintatapoihin ja käytäntöihin, joilla kuntalaisten osallistumista ja vaikuttamista vahvistetaan heitä koskevassa päätöksenteossa. Osallisuusmallien laatimisessa ei ole kyse pelkästään suomalaisesta ilmiöstä, vaan kansainvälisestä kehityksestä, jossa paikallishallinnot ympäri maailman pyrkivät kehittämään toimintatapojaan ja käytäntöjään vahvistaakseen kansalaisten osallistumismahdollisuuksia erilaisissa päätöksenteon kysymyksissä ja vaiheissa (Ravazzi 2016).

Osallisuusmallien kehittäminen voidaan nähdä osoituksena tietoisesta hallinnollisesta suunnittelusta, jossa paikallishallinto pyrkii vastaamaan koettuun demokratiavajeeseen tarjoamalla kansalaisille erilaisia tapoja osallistua ja vaikuttaa. Lisäksi kokoamalla erilaiset osallistumista säätelevät tavoitteet, periaatteet ja menetelmät osallisuusmalleihin ja -strategioihin hallinto voi osoittaa, että se toimii lainsäädännöstä tulevien vaatimuksien toteuttamiseksi (Lewanski 2013; Steiner 2012) sekä osallistumista säätävien normien ja käytäntöjen selkeyttämiseksi "hyvän hallinnon" periaatteiden täyttämiseksi (Tahvilzadeh 2015). 
Toisaalta osallisuusmalleja voidaan kritisoida siitä, että ne pohjautuvat ylhälltä alaspäin suuntautuvalle hallintolähtöiselle osallistamiselle (Blaug 2002; 2010). Tässä viitekehyksessä osallistuminen nähdään hyväksyttävänä, mikäli se tapahtuu hallinnon rajaamissa ja säätelemissä puitteissa (Jäntti ym. 2017). Viranhaltijoilla on huomattavaa valtaa säädellä osallistumista esimerkiksi päättämällä, missä vaiheessa kuntalaiset voivat osallistua valmisteluun ja päätöksentekoon, sekä kontrolloimalla, kuinka kuntalaisten toiveet, tarpeet ja mielipiteet huomioidaan päätöksenteossa (Leino 2006). Tästä syystä onkin tärkeää kartoittaa, miten osallistumisen toteuttamisesta vastuussa olevat viranhaltijat suhtautuvat kansalaisiin ja heidän osallistumismahdollisuuksiinsa.

Tämän tutkimuksen tavoitteena on lisätä tietoa johtavien viranhaltijoiden asenteista ja suhtautumisesta kansalaisosallistumista kohtaan paikallishallinnon yhteydessä. Toistaiseksi tutkimukset kansalaisosallistumisesta ovat Suomessa keskittyneet pääasiassa kansalaisten käsityksiin ja kokemuksiin osallistumisesta. Tutkimuksissa on tarkasteltu muun muassa, miten osallistujat itse arvioivat erilaisia osallistumismenetelmiä (Christensen 2015; Lundell ym. 2016), ja millainen käsitys laajemmalla yleisöllä on uusista kansalaisosallistumisen muodoista (Jäske 2018). Vähäisemmälle huomiolle ovat jääneet poliitikkojen sekä viranhaltijoiden käsitykset kansalaisosallistumisesta. Erityisesti kuntien päättävissä asemissa toimivien viranhaltijoiden asenteita ja suhtautumista osallistumista kohtaan on tutkittu toistaiseksi vain vähän.

Tutkimuksessa tarkastellaan: 1) Miten viranhaltijat määrittelevät kuntalaisosallistumisen merkitystä kunnallisessa päätöksenteossa?2) Mitä taustatekijöitä viranhaltijat pitävät merkittävinä suhteessa osallistumiskanavien integroimiseen osaksi kuntahallintoa? Tutkimuskysymyksiin etsitään vastausta tarkastelemalla Turun kaupungin johtavien viranhaltijoiden käsityksiä osallistumisen toteutumisesta sekä osallistumisen toteutumiseen liittyvistä tekijöistä. Turun kaupunki tarjoaa mielenkiintoisen kohteen tutkimusaiheen käsittelyyn, sillä kaupungilla on jo vuosien kokemusta osallistumisen toteuttamiseen liittyvistä haasteista ja uuden osallisuusmallin tarve on ilmeinen. Tutkimuksen tulokset lisäävät ymmärrystä kuntalaisten osallistumistapo- jen omaksumisen ja vakiinnuttamisen haasteista ja luovat pohjaa parempien toimintatapojen ja käytäntöjen kehittämiseksi.

Tutkimusartikkeli etenee seuraavasti: Aluksi artikkeli esittelee lyhyesti tutkimuksen teoreettista näkökulmaa koskevaa tutkimuskirjallisuutta. Tässä tutkimuksessa osallisuusmallien nähdään olevan yhteydessä demokratiateoriaa koskevassa tutkimuksessa käynnissä olevaan keskusteluun instituutioiden muotoilusta ("institutional design"), joka tähtää uudenlaisten osallistumismenetelmien integroimiseen osaksi hallinnollista ja poliittista järjestelmää (Hendriks 2016; Thompson 2008). Tutkimuksen empiirisessä osiossa tarkastellaan viranhaltijoiden asenteita kuntalaisosallistumista kohtaan sekä käsityksiä erilaisista hallinnon ja kansalaisosallistumisen muotojen integraatioon vaikuttavista institutionaalisista taustatekijöistä. Tutkimuksen tulosten perusteella Turun kaupungissa osallistumisen haasteet liittyvät erityisesti lainsäädäntöön, organisaation ja viranhaltijoiden valmiuksiin sekä kuntahallinnossa vallitsevaan poliittiseen kulttuuriin.

\section{TUTKIMUSTEOREETTINEN KATSAUS OSALLISTUMISEN INSTITUTIONAALISIIN EDELLYTYKSIIN}

Kuntalaisten osallistuminen päätöksentekoon toteutuu perinteisesti edustuksellisen demokratian toimintatapojen kautta, jolloin kuntalaiset voivat vaikuttaa siihen, ketkä heitä edustavat kunnan valtuustossa ja hallituksessa. Lisäksi kuntalaisille on tarjolla suoria osallistumis-, vaikuttamis- ja palautteenantokanavia, joissa he voivat esittää näkemyksensä valmisteltaviin ja päätettäviin asioihin (Pekola-Sjöblom 2013) sekä vaikuttaa heille tarjottaviin palveluihin (Jäppinen 2013). Viime vuosikymmenien aikana ovat myös yleistyneet uudenlaiset osallistumismenetelmät, eli demokratiainnovaatiot, jotka tarjoavat kuntalaisille vaihtoehtoisia tapoja vaikuttaa heitä koskeviin päätöksiin (Smith 2009). Esimerkkinä uusista osallistumismenetelmistä ovat muun muassa kuntalaisaloitteet- ja raadit, osallistuva budjetointi sekä erilaiset digitaaliset vuorovaikutuskanavat (Newton 2012). Näiden käyttö on yleistynyt tasaisesti Suomen kunnissa 2000-luvun aikana (Christensen ym. 2016).

Kansalaisten suoralla osallistumisella on to- 
dettu olevan monia myönteisiä vaikutuksia päätöksentekoon. Osallistumisen kautta saadaan tietoa päätökseen liittyvistä kysymyksistä, jolloin päättäjillä on parempi käsitys siitä, millaisia seikkoja päätöksiä tehtäessä on otettava huomioon ja millaisia vaikutuksia erilaisilla päätöksillä voi olla (Michels 2012). Lisäksi tutkimuksessa on havaittu, että osallistuminen lisää kansalaisten kokemusta päätöksenteon legitimiteetistä (Michels \& de Graaf 2010), vahvistaa kansalaisten demokratiataitoja ja ymmärrystä päätöksenteon vaativuudesta (Michels 2011), edistää luottamusta poliittista järjestelmää kohtaan (Adenskog 2018) sekä luo myönteistä käsitystä omista vaikutusmahdollisuuksista (Nabatchi 2010).

Toisaalta kokemukset osallistumisesta eivät ole yksinomaan myönteisiä, vaan osallistumisen toteutumiseen on liitetty myös ongelmia, jotka voivat johtaa jopa demokratian heikentymiseen. Esimerkiksi aikaisemmassa tutkimuksessa on todettu, että osallistuminen koskee useimmiten vain hyvin vaatimattomia kysymyksiä (Michels 2011; 2012; Sintomer ym. 2008), osallistuminen vahvistaa jo muutenkin aktiivisen poliittisen valtaeliitin asemaa (Michels 2012; Blakeley 2010), ja osallistumista käytetään tiettyjen intressien edistämiseen sekä jo tehtyjen päätösten legitimoimiseen (Tahvilzadeh 2015).

Osallistumismahdollisuuksien puutteiden tunnistaminen on tärkeää, sillä kansalaisten huonot kokemukset osallistumisesta voivat johtaa pettymyksiin sekä luottamuksen rapautumiseen poliittista järjestelmää ja päättäjiä kohtaan (Christensen 2015). Tutkijat ovat esittäneet, että merkittävänä syynä erilaisten osallistumismenetelmien vaikeuksiin ovat niiden heikot kytkökset vallitsevaan poliittiseen järjestelmään (Hendriks 2016). Koska uudet osallistumiskanavat eivät ole yhteydessä edustuksellisen demokratian toimintatapoihin ja -malleihin, kansalaisten esittämät ehdotukset eivät tule huomioiduksi poliittisissa prosesseissa. Tämä lisää tarvetta sellaisten toimintamallien ja käytäntöjen kehittämiseksi, joilla uudenlaiset kansalaisosallistumisen tavat ja mallit voidaan integroida paremmin osaksi edustuksellista poliittista järjestelmää (Setälä 2017).

Viime vuosien aikana demokratiateorian tutkijoiden keskuudessa on herännyt keskustelu instituutioiden muotoilusta, jolla viitataan pyr- kimykseen kehittää toimintatapoja ja käytäntöjä, joilla kansalaisten suoria osallistumiskanavia voidaan hyödyntää erilaisissa julkisen päätöksenteon prosesseissa (Hendriks 2016; Thompson 2008). Tämän käsityksen mukaan erilaisilla kansalaisosallistumisen muodoilla voi olla erilaisia tehtäviä osana julkista päätöksentekoa ja poliittista järjestelmää (Curato \& Böker 2016; Hendriks 2016). Yksittäisten toimintamallien tutkimuksen sijaan tutkijat ovat kiinnostuneita siitä, miten demokraattisen päätöksenteon periaatteet toteutuvat systeemitasolla. Systeemisen ajattelun mukaan erilaisilla osallistumistavoilla ja -malleilla voi olla toisiaan täydentäviä piirteitä, jotka voivat edistää demokraattisemman päätöksenteon toteutumista (Mansbdrige ym. 2012). Tällöin huomio kiinnittyy siihen, kuinka poliittinen päätöksenteko tulee järjestää ja organisoida niin, että erilaisten toimintamallien kautta kerätty tieto kansalaisten mielipiteistä ja toiveista voidaan integroida osaksi päätöksentekoprosesseja tarkoituksenmukaisella tavalla. Tärkeää on, että uudet osallistumismenetelmät eivät vaaranna järjestelmän toiminnan arvioimisen kannalta tärkeitä periaatteita muun muassa päätösten oikeudenmukaisuudesta sekä päätöksentekijöiden tilivelvollisuudesta.

Toisaalta instituutioiden muotoilua on kritisoitu siitä, että se voi johtaa osallistumisen hallinnollistumiseen. Tällä viitataan hallinnon pyrkimykseen hallita ja rajoittaa kansalaisosallistumista tiettyjen ennalta asetettujen ja muodollisten rajojen puitteissa (Dryzek \& Tucker 2008). Osa tutkijoista myös uskoo, että valtaapitävät voivat käyttää osallistumismenetelmiä strategisesti edistääkseen omia intressejään. Päättäjät edistävät vain sellaisia kansalaisten aloitteita, jotka edistävät tiettyjen poliittisten pyrkimysten saavuttamista (Niinikoski \& Setälä 2015, 25) tai ovat linjassa kunnan toimintaa ohjaavien linjausten ja suunnitelmien kanssa (Häikiö ym. 2016). Samalla luodaan perusteita vakiintuneiden ja sovinnaisten osallistumiskanavien ulkopuolelta tulevien mahdollisten kriittisten äänenpainojen sivuuttamiseksi sekä leimaamiseksi ei-legitiimeiksi.

Huomionarvoista on, että instituutioiden muotoilu kiinnittää huomion institutionaaliseen osallistumiseen, mikä viittaa virallisiin hallintorakenteisiin ja niiden puitteissa tapahtuvaan hallintolähtöiseen ja -pohjaiseen kansalai- 
sosallistumiseen (Jäntti ym.2017). Tämä rajaa tarkastelun ulkopuolelle useita tärkeitä ja merkityksellisiä osallistumisen tapoja, kuten suora kansalaisosallistuminen ja muut virallisen järjestelmän ulkopuolella toimivat asukkaiden verkostot ja ryhmittymät (ks. Rättilä \& Rinne 2017). Nämä voivat tarjota kansalaisille vaihtoehtoisen tavan vaikuttaa silloin, kun muodolliset kanavat ovat syystä tai toisesta toimimattomia.

\section{Institutionaaliset resurssit}

Erilaisia julkisen hallinnon omaksumia kansalaisten osallistumismenetelmiä on tutkittu runsaasti viime vuosikymmenien aikana. Empiirisessä tutkimuksessa on todettu, että uusien osallistumiskanavien omaksuminen osaksi hallinnon suunnittelu- ja päätöksentekojärjestelmää ei tapahdu kitkattomasti vaan edellyttää suotuisten taustatekijöiden olemassaoloa. Osallistumisen edellytyksenä on muun muassa se, että hallinnolla on käytössään riittävät taloudelliset kannusteet sekä resurssit (Bherer 2010), osallistumista koskeva oikeudellinen sääntely luo osallistumiselle tarpeeksi vahvat lainsäädännölliset puitteet (Jäske 2019; Nabatchi \& Amsler 2014), hallinnossa vallitsee osallistumista arvostava poliittinen kulttuuri (Nabatchi \& Amsler 2014) sekä hallinnossa on osallistumiseen liittyviä perinteitä (Sintomer ym. 2008).

Aikaisemman tutkimuksen valossa on ilmeistä, että hallinnon sisäiset valmiudet ovat avainasemassa uusien kansalaisosallistumisen kanavien omaksumisessa ja vakiinnuttamisessa osaksi julkishallintoa. Toisaalta toistaiseksi aikaisemmassa tutkimuskirjallisuudessa on pääasiassa keskitytty tarkastelemaan yksittäisten osallistumistapojen edellytyksiä tai osallisuusmallin varhaista käyttöönottoa. Tällöin tutkimuksen tavoitteena on ollut vastata ennen kaikkea kysymykseen, miksi tietty kansalaisosallistumisen muoto tai malli on otettu käyttöön, ja millaiset tekijät ovat johtaneet mallin käyttöönottoon (ks. Bherer 2010; Font ym. 2014; Ravazzi 2016). Vähäisemmälle huomiolle on jäänyt vallitsevan mallin toteutumiseen vaikuttavien tekijöiden tarkastelu.

Tässä artikkelissa tarkastellaan empiirisen tutkimuksen valossa kansalaisosallistumisen toteutumiseen liittyviä valmiuksia paikallishallinnon yhteydessä erityisesti ylimmän virkamies- johdon näkemysten kautta. Tutkimuksen tulokset lisäävät ymmärrystä siitä, minkälaisia ongelmia kansalaisosallistumisen toteuttamisessa johtavat viranhaltijat näkevät olevan paikallishallinnon piirissä. Haastateltavat viranhaltijat muodostavat erityisen mielenkiintoisen tutkimuskohteen, koska he ovat virka-asemansa puolesta hyvin asemoituneita kansalaisosallistumisen ja julkishallinnon kokonaiskuvan suhteen. Johtavat viranhaltijat ovat myös keskeisiä päättäjiä, kun kaupunki päättää, millä tavalla se osallistumista konkreettisesti jatkossa toteuttaa.

\section{AINEISTO JA ANALYYSIMENETELMÄT}

Tutkimuksessa tarkastelun kohteena ovat Turun kaupungin johtavien viranhaltijoiden käsitykset kuntalaisten osallistumisen toteutumisesta kaupungissa. Turun kaupungin nykyinen osallisuusmalli pohjautuu muun muassa kaupungin hallintosäännössä (67 §) (Turun kaupungin hallintosääntö) sekä kaupunkistrategiassa (Turku 2029 - pohjoisen Itämeren kiinnostavin kaupunki) esitettyihin tavoitteisiin. Strategian mukaan kaupungin tavoitteena on antaa kaupungin asukkaille mahdollisuus vaikuttaa palveluiden suunnitteluun sekä kaupungin kehittämiseen erityisesti kaupunkilaisten omassa lähiympäristössä. Kaupunki tarjoaa asukkaille erilaisia tapoja vaikuttaa asioiden valmisteluun, päätöksentekoon sekä päätösten toteuttamiseen. Kaupungissa on käytössä muun muassa kaupunkilaisten vaikuttajaryhmiä, aluefoorumeita, asiakasraateja, eri teemoihin keskittyneitä kuntalaisraateja, palautteenantokanavia, kuulemistilaisuuksia sekä talkootoimintaa ja palveluiden yhteistuotantoa yhdessä kaupunkilaisten sekä yhdistysten kanssa. Laajasta keinovalikoimasta huolimatta kaupungin osallistamisen ei koeta olevan riittävää eikä toimivaa. Tästä johtuen pyrkimyksenä on nyt luoda uusi osallisuusmalli, jossa asukkaiden rooli päätöksenteossa merkittävästi kasvaisi.

Tutkimusta varten haastateltiin 15 kaupungin keskushallinnon sekä toimialojen johdossa toimivaa viranhaltijaa syys- ja lokakuussa vuonna 2018. Haastattelut tehtiin osana Strategisen tutkimuksen neuvoston rahoittaman Osallistuminen pitkäjänteisessä päätöksenteossa (PALO) -tutkimushankkeen yhteistyötä Turun kaupungin kanssa. Haastattelujen kohteeksi valittiin 
kaupungin ylimmän virkamiesjohdon edustajat, koska he ovat kansalaisosallistumisen ja hallinnon integroimisen sekä koko kaupungin kattavan osallisuusmallin läpiviennin kannalta avainhenkilöitä. Viranhaltijoiden haastattelujen kautta on mahdollista saada edustava käsitys kuntalaisosallistumisen nykytilasta Turun kaupungissa, sillä toisin kuin poliitikoilla, monilla viranhaltijoilla on pitkä ja laaja kokemus kunnallisesta päätöksenteosta sekä kuntalaisosallistumisen integroimisesta osaksi vakiintuneita toimintatapoja. Viranhaltijoiden on myös mahdollista puhua avoimemmin kuntalaisosallistumiseen liittyvästä mahdollisesta "politisoinnista", kuin vaaleilla valittavien poliitikkojen.

Haastatteluissa vastaajilta kysyttiin heidän käsityksiään muun muassa osallistumisen määritelmästä, osallistumisen merkityksestä vastaajan edustaman yksikön toiminnassa sekä osallistumisen toteutumiseen vaikuttavista tekijöistä. Kysymyspatteristoon kuuluivat muun muassa seuraavat kysymykset: Kartoitetaanko yksikössäsi kuntalaisten mielipiteitä, ja millä tavoilla? Mitä olette havainneet toimiviksi käytännöiksi? Mikä tällä hetkellä on suurin ongelma osallistumisen suhteen yksikössäsi? Koetko, että kuntalaisten osallistumisella ja heidän ehdotuksillaan on vaikutuksia päätösten valmisteluun omassa yksikössäsi? Mitkä tekijät estävät kuntalaisten mielipiteiden huomioimisen valmistelussa ja päätöksenteossa? Minkälaisena näet konsernihallinnon roolin osallistumisessa suhteessa toimialaan? Miten osallistuminen huomioidaan tai pitäisi huomioida kaupungin viranhaltijoiden toimenkuvissa?

Haastatteluiden kesto vaihteli 15 minuutista tuntiin. Yhtä vaille kaikki haastatteluihin kutsutuista viranhaltijoista osallistuivat haastatteluihin. Kaikki haastattelut toteutettiin yksilöhaastatteluina lukuun ottamatta yhtä haastattelua, johon osallistui kaksi haastateltavaa. Haastatteluiden litterointi toteutettiin tilaustyönä Tutkimustie Oy:ssä. Artikkelissa käytetyissä lainauksissa vastaajien nimet ovat anonymisoitu, jotta heidän henkilöllisyyttään ei pystytä tunnistamaan. Myös tekstissä olevat sitaatit on muotoiltu puhekielestä kirjakieleksi, jotta niitä ei voida yhdistää yksittäisiin viranhaltijoihin.

Haastattelujen analyysi perustuu temaattiselle sisällönanalyysille, jossa haastattelujen sisältö tiivistettiin tutkimustehtävän kannalta keskei- siin sitaatteihin. Samaa asiaa käsittelevät haastattelusitaatit koottiin niitä yhdistäviin luokkiin, jotka lopuksi ryhmiteltiin jonkin laajemman teeman alle, mikäli sellainen oli tunnistettavissa. Aineistosta abstrahoidut teemat liittyvät muun muassa kuntalaisosallistumisen määrittelyyn, tavoitteisiin sekä toteutumiseen. Erityisesti aineiston analyysin tarkoituksena on tunnistaa erilaisia tekijöitä, joiden haastatteluihin osallistuneet viranhaltijat kokevat vaikeuttavan osallistumisen toteutumista Turun kaupungissa.

\section{TULOKSET}

\section{Osallistumisen toteutuminen Turun kaupungissa}

Haastatteluihin osallistuneet viranhaltijat kertovat osallistumisen toteutuvan Turun kaupungissa monin eri tavoin. Toiset vastaajista näkevät osallistumisen pelkästään kuulemisena, kun taas toisten mukaan osallistuminen voi olla myös konkreettisten päätösten tekemiseen sekä päätösten toteuttamiseen tähtäävää vaikuttamista. Yksi viranhaltijoista näkee osallistumisen myös konkreettisena tekemisenä, joka tapahtuu erityisesti yhteistyössä kaupungin ja kaupunkilaisten kanssa esimerkiksi talkootyön kautta.

Haastattelut osoittavat, että kuntalaisten osallistumisella koetaan olevan erilaisia myönteisiä vaikutuksia kunnan päätöksenteolle. Osallistuminen edistää kaupungin rajallisten taloudellisten resurssien hyödyntämistä antamalla päättäjille paremman käsityksen kuntalaisten todellista tarpeista, jolloin investoinnit voidaan suunnata tehokkaammin juuri sellaisiin asioihin, joita kuntalaiset pitävät kaikkein tärkeimpinä. Kuntalaisten kuulemisen myötä päättäjillä on mahdollisuus tehdä päätöksiä, jotka ottavat paremmin huomioon päätösten vaikutukset asuinalueen asukkaisiin, palveluiden käyttäjiin sekä muihin mahdollisiin asiaosaisiin. Tämä vahvistaa tehtyjen päätösten legitimiteettiä ja lisää kuntalaisten valmiutta hyväksyä tehdyt päätökset, vaikka ne eivät täysin vastaisikaan heidän omia yksityisiä intressejään. Näin kuntalaisten kuuleminen voi vähentää myös päätöksiin kohdistuvaa kritiikkiä.

Osa vastaajista on sitä mieltä, että osallistuminen voi myös lisätä osallistujien sosiaalista kiinnittyneisyyttä. Osallistumalla elinympäris- 
töönsä kehittämiseen kuntalaiset voivat tuntea kuuluvansa osaksi laajempaa yhteisöä. Näin osallistuminen ruokkii osallisuutta, jonka on nähty olevan yksi osallistumisen rinnakkaiskäsitteistä. Perinteisen käsityksen mukaan osallisuus kuvaa kuulumista osaksi laajempaa yhteisöä, kun taas osallistuminen viittaa todellisiin mahdollisuuksiin tuoda esiin mielipiteitään ja vaikuttaa tehtäviin päätöksiin (Nivala \& Ryynänen 2013). Toisaalta osallistumisen sekä osallisuuden voidaan katsoa olevan toisiinsa läheisesti yhteydessä. Erityisesti aktiivisen kansalaisuuden kehyksessä kansalaisten osallistumisen yhteiskunnan eri toimintoihin on katsottu olevan sosiaalisen kiinnittyneisyyden edellytys (Myllyniemi 2013).

Kahdeksan haastatteluihin osallistuneista viranhaltijoista edustivat kaupungin toimialojen johtoa, joten monet vastaajista arvioivat osallistumisen toteutumista erityisesti oman toimialansa näkökulmasta. Haastatteluiden perusteella on ilmeistä, että Turun kaupungissa osallistuminen toteutuu vaihtelevasti eri toimialoilla. Vaikka osallistumista toteutetaan kaikilla toimialoilla jossain muodossa, toisilla toimialoilla sen toteuttaminen on haastavampaa kuin toisilla. Erityisesti vapaa-aikatoimessa sekä kaupunkiympäristötoimialalla asukkaita kuullaan suhteellisen paljon, kun taas hyvinvointitoimialalla osallistumisen toteuttaminen on vaikeampaa. Toisaalta yksi vastaajista kertoo, että myös hyvinvointitoimialalla on viime vuosien aikana otettu käyttöön toimintamalleja, jotka ovat edistäneet palveluiden käyttäjien osallistumismahdollisuuksia.

Yleisesti ottaen haastattelut osoittavat osallistumisen vaikuttavuuden olevan yksi sen haasteista. Tämä vastaa aikaisempia tutkimuksia, jotka ovat tarkastelleet osallistumisen vaikutuksia erilaisissa julkisen päätöksenteon kysymyksissä. Vaikka kansalaisille on tarjolla laajasti erilaisia mahdollisuuksia osallistua päätöksentekoon ja valmisteluun, osallistumisen vaikutukset päätöksiin jäävät usein varsin vähäisiksi (Johnson 2015; Michels 2011). Yksi ympäristötoimialalla toimivista vastaajista kuvailee osallistumista toimialallaan seuraavasti:

"Kyllä siinä kaavassa koitetaan saada erilaisten viranomaisten, sekä myös yksityisten ihmisten mielipiteet huomioiduksi. Ei kaikissa kaavoissa tokikaan. Osa kaavoista on niitä, jotka ikään kuin menevät eteenpäin kuin jyrä.” (VH12)

Vaikuttavuuden ohella toisena toistuvana ongelmana osallistumisessa on vinoutumat osallistujien edustavuudessa. Kaupungin hyödyntämien osallistumiskanavien ongelmana on se, että niitä käyttävät kuntalaiset eivät välttämättä edusta koko kaupungin väestöä. Tämä tukee aikaisempia havaintoja osallistumisen kasaantumisesta usein jo muutenkin aktiivisille ja hyvin toimeentuleville kansalaisille ja ryhmille (Pihlaja \& Sandberg 2012). Suurena haasteena kaupungilla onkin tavoittaa sellaisia kuntalaisia, jotka olisivat eniten palveluiden tarpeessa.

"Sitten pitää tietysti mainita sekin, että palautetta antavat usein aktiiviset ihmiset, joilla on vahva mielipide. Se ei kuitenkaan välttämättä vastaa sen koko alueen enemmistön mielipidettä johonkin asiaan. Pitää pystyä tunnistamaan, että onko kysymyksessä semmoinen malli, missä kuunnellaan sitä, joka huutaa kovimmin, vai semmoinen malli, missä selvitetään, mistä kokonaisuudessa on kyse. Ei ole helppoa tehdä aidosti ja oikeasti osallistavaa ja kaikki huomioivaa mallia." (VH9)

Erityisessä vaarassa jäädä osallistumiskanavien ulkopuolelle ovat nuoret sekä maahanmuuttajat. Nuorten tavoittamisen kannalta kynnyskysymyksenä on monien vakiintuneiden osallistumiskanavien raskaus, mikä viitaa kanavien vaatimaan sitoutumiseen. Vastaavia havaintoja on tehty myös aikaisemmassa tutkimuksessa, jossa suurimpina syinä nuorten osallistumattomuuteen on todettu olevan mielekkäiden osallistumistapojen löytymättömyys sekä ajanpuute (Myllyniemi 2013, 23). Esimerkiksi nuorten vaikuttajaryhmät vaativat vastaajien mielestä jäseniltään suuria ajallisia resursseja, joihin suurimmalla osalla nuorista ei ole varaa. Maahanmuuttajien osallistumista hankaloittavat erityisesti puutteelliset kielitaidot, jonka seurauksena maahanmuuttajilla ei välttämättä ole edes tietoa heidän käytettävissään olevista osallistumiskanavista.

Myöskään uudenlaisten vaihtoehtoisten osallistumiskanavien hyödyntäminen ei välttämättä korjaa osallistumisen keskittymiseen ja eriytymiseen liittyviä epäkohtia. Osalla kuntalai- 
sista ei ole käytössään tarvittavaa tekniikkaa ja osaamista kanavien käyttämiseen. Esimerkiksi digitaalisten vuorovaikutus- ja palautteenantokanavien käyttö voi vaatia kuntalaisilta erilaisia tiedollisia, taidollisia sekä taloudellisia resursseja (ks. Matikainen 2008, 23). Tästä syystä digitaalisten tekniikoiden yleistyminen kuntalaisosallistumisessa saattaa jopa vahvistaa osallistumisen eriytymistä.

"Toinen haaste sitten on siinä, että miten saadaan aktivoitua ne ihmiset, jotka eivät niin helposti muutenkaan osallistu yhteiskuntaan, ja ovat sitä väestöryhmää, joille erityisesti pitäisi tarjota tukea ja erilaisia palveluita. Puhutaan vaikka digitalisaatiosta, tai oikeastaan mistä tahansa kanavasta, niin kyllä ne kaikkein aktiivisimmat ja parhaiten voivat ihmiset melkein eniten ovat siellä äänessä. Se on ehkä varmaan se osallisuuden yksi isoin haaste." (VH10)

\section{Osallistumisen toteutumiseen vaikuttavia institutionaalisia taustatekijöitä}

Tutkimusta varten haastateltujen viranhaltijoiden näkökulmasta osallistumisen toteutumiseen vaikuttaa lukuisia tekijöitä, jotka liittyvät muun muassa kuntalaisten osallistumista säätelevään lainsäädäntöön sekä ohjaukseen, kaupungin osallistumisstrategian kattavuuteen, eri tahojen roolien selkeyteen sekä osallistumista edistävien viranhaltijoiden asenteisiin ja osaamiseen. Seuraavassa on esitelty lyhyesti eri osallistumiseen vaikuttavat taustatekijät.

\section{Lainsäädäntö}

Yhden osatekijän osallistumisen toteuttamisessa muodostaa voimassa oleva lainsäädäntö (Jäske 2019; Nabatchi \& Amsler 2014). Haastatteluiden perusteella lainsäädännöllä on vaihteleva rooli eri toimialoilla. Erityisesti kaupunkiympäristötoimialalla maankäyttö- ja rakennuslaki takaa vähimmäistason muun muassa suunnitelmien julkisuutta sekä asukkaiden kuulemista koskien. Muilla toimialoilla lainsäädäntö takaa huomattavasti heikommat reunaehdot osallistumisen toteuttamiseksi. Tästä johtuen toimialoilla ei ole käytössään yhtä vakiintuneita menettelyitä ja käytäntöjä kuntalaisten antaman palautteen ja kannanottojen integroimiseen osaksi valmisteluja päätöksentekoprosessia. Puutteellinen lainsäädäntö voi vaikeuttaa kansalaisten osallistumismahdollisuuksia myös esimerkiksi verkkopohjaisessa osallistumisessa (vrt. Matikainen ym. 2008).

"Kaavallisissa kysymyksissä ja sellaisissa kysymyksissä, joissa osallisuus tulee maankäyttöja rakennuslain nojalla, niin siellä kaikki ne lausunnot, joita virallisesti on kaavasuunnitelmaan jätetty, on aina oltava oheismateriaalina mukana. Mutta muissa asioissa tällaista vaatimusta ei ole. Meille tulee hyvin paljon sen tyyppisiä kannanottoja, joita ei sitten sinne päätöksentekoon eteenpäin viedä. Mikään järjestelmä ei sellaista edellytä. Meillä ei myöskään ole sellaista järjestelmää, jossa ihmiset pystyisivät todentamaan, että heidän omat näkemyksensä ovat mukana siinä kyseisen asian käsittelyssä, niin että ne ainakin minimissään olisivat huomioitu." (VH2)

Toisaalta tiukka lainsäädäntö voi asettaa ympäristötoimialalla toimiville viranhaltijoille myös kohtuuttomia vaatimuksia. Esimerkiksi yksi vastaajista kertoo, että julkiseksi asetetut kaavasuunnitelmat saavat usein niin runsaasti kirjallista palautetta, ettei viranhaltijoilla ole mahdollisuutta vastata kaikkiin annettuihin. Lisäksi kommentteihin vastaaminen ja niiden huomioiminen vaativat viranhaltijoilta usein pitkällistä harkintaa, sillä kirjallisia vastauksia voidaan mahdollisesti käyttää hallinto-oikeuteen tehtävien valitusten perusteluissa.

\section{Organisatoriset valmiudet}

Organisatoriset valmiudet viittaavat organisaation sisäisiin tekijöihin, jotka mahdollistavat ja heikentävät osallistumisen toteutumista. Voimassa olevan lainsäädännön puitteissa kunnat voivat määritellä suhteellisen itsenäisesti, kuinka ne toteuttavat osallistumista alueellaan (Christensen ym. 2016). Kuntalaisten osallistumista säätelevät muun muassa erilaiset kunnassa vaikuttavat toimintatavat ja käytännöt, jotka viittaavat erilaisiin menettelyihin, joiden avulla kuntalaislähtöiset suunnitteluprosessit yhdistetään hallintolähtöiseen suunnittelu- ja päätöksentekojärjestelmään. Nämä voivat perustua julkisiin lin- 
jauksiin, ohjeisiin ja sääntöihin, jotka ohjaavat eri hallinnon alojen sekä viranhaltijoiden toimintaa (Font ym. 2014; Ganuza \& Baiocchi 2012).

Haastatteluiden perusteella Turun kaupungin nykyinen strategia tukee nykyisellään hyvin osallistumista ja viime vuosien aikana kaupungin strategiset tavoitteet ovat alkaneet "arkipäiväistyä" ja näkyä entistä enemmän käytännön toiminnassa. Toisaalta osa vastaajista suhtautuvat kaupungin strategiaan kriittisemmin kuin toiset. Vaikka tahtoa osallistumisen edistämiseen löytyy, se ei kuitenkaan aina kanna käytännön toteutukseen asti.

"Siellä kaupunkistrategiassa on vahva painotus siihen, että kaupunkia tehdään yhdessä kumppaneiden ja erityisesti kaupunkilaisten kanssa. Mutta esimerkiksi johtoryhmäkeskustelussa aika harvoin nousee ihan sana osallistaminen esiin. Toki se asia on tiedostettu ja monella on hyvä tahto edistää sitä, mutta käytännön toteutuksessa halu ja käytäntö ovat vielä aika kaukana toisistaan." (VH3)

Yhtenä osallistumisen edistämisen suurena ongelmana on nykyisellään toiminnan lyhytjänteisyys. Osallistumista toteutetaan usein ajallisesti rajattujen projektien puitteissa. Tästä syystä osallistuminen loppuu kulloisenkin projektin päättyessä, eikä osallistumismenetelmien ja suunnittelu- ja päätöksentekojärjestelmän välille ehdi syntyä pysyvää yhteyttä. Lyhytjänteisyys ja projektimaisuus kuvaavat osallistumisen ominaispiirrettä suomalaisessa kuntakentässä laajemminkin (Kuokkanen 2016). Vain harvassa kunnassa demokratiakysymykset on otettu systemaattisesti suunnittelun ja päätöksenteon agendalle. Tästä johtuen monet osallistumisen edistämiseen pyrkivät prosessit ovat jääneet irrallisiksi projekteiksi suhteessa edustuksellisen demokratian valmistelu- ja päätöksentekokäytäntöihin (Bäcklund \& Kallio 2012; Häikiö 2005).

Osallistumisen toteutumista heikentää myös se, että osallistuminen hajaantuu eri toimialoille, joiden välillä ei tapahdu yhteistyötä eikä vuorovaikutusta. Tämä johtaa hallinnon "siiloutumiseen", eli toimintojen hajaantumiseen eri toimialoille. Siilojen muodostuminen heijastuu tiedonkulun katkoksissa organisaation sisällä sekä työntekijöiden välillä. Haastatteluissa toistuvana piirteenä nousee esiin se, ettei kaikilla vastaajilla ole selvillä, millä tavoin kuntalaisten osallistumista kaupungissa edistetään, mitkä tahot osallistumisen edistämisestä vastaavat ja millaisia tukitoimintoja osallistamiseen on käytettävissä.

Merkittävänä haasteena osallistumisessa myös sen, ettei kaupungilla ole käytössään käytäntöjä sekä työkaluja osallistumisen vaikutusten arvioimiseksi ja todentamiseksi. Osallistumisen seurannan puuttuessa kuntalaisilla ei ole mahdollisuutta arvioida, kuinka heidän äänenä on otettu huomioon päätöksenteossa. Päättäjillä ja kaupunkilaisilla ei myöskään ole mahdollisuutta arvioida laajemmin osallistumisen vaikuttavuutta sekä kunnan osallistumistavoitteiden toteutumista. Yksi vastaajista kuvaa tilannetta seuraavasti:

"No se mikä tässä on yksi iso haaste, niin on se, miten me todennetaan se, että olemme osallistaneet, ihmiset ovat osallistuneet ja ihmisten kokemukset osallistumisesta ovat parantuneet." (VH4)

\section{Yksilölliset valmiudet}

Yksilölliset valmiudet viittaavat kuntalaisten osallistumista toteuttavien viranhaltijoiden henkilökohtaisiin asenteisiin, taitoihin ja kykyihin. Vaikka osallistumisen toteuttaminen on pitkälle säädeltyä olemassa olevan lainsäädännön sekä kunnan sisäisten strategioiden ja linjausten kautta, yksittäisillä viranhaltijoilla on suhteellisen suuri rooli strategioiden ja linjausten "jalkauttamisessa". Tämä korostaa yksittäisten viranhaltijoiden valmiuksien merkitystä osallistumisen toteuttamisessa. Yhtenä merkittävänä tekijänä osallistumisen toteutumisessa muodostaa viranhaltijoiden käytössä oleva työaika. Erilaisten yleisötilaisuuksien sekä kuulemisten valmisteleminen sekä toteuttaminen vaativat viranhaltijoilta merkittäviä ajallisia resursseja. Lisäksi viranhaltijat joutuvat työssään vastaamaan erilaisten sähköisten palautteenantokanavien kautta annettuun palautteeseen usein päätyönsä ohessa. Tällöin heillä ei useinkaan ole mahdollisuutta käyttää työaikaansa jokaisen päätökseen annetun palautteen huomioimiseksi sekä erilaisten toiveiden yhteensovittamiseksi niin hyvin kuin he toivoisivat. 
"Jos pelkästään yhteen suunnitelmaan tulee 50 mielipidettä, niin yhdellä viranhaltijalla menee kuukausi siihen, että hän miettii, miten hän niihin vastaa fiksusti. Ja sitten kun yleensä se on vaan kielteistä palautetta, niin miten ihmeessä ihmistä motivoidaan siihen?" (VH13)

Suurena ongelmana osallistumisen toteuttamisessa on myös se, ettei kaikilla viranhaltijoilla ole käytössään tarvittavia taitoja ja kykyjä osallistumisen suunnitteluun ja toteuttamiseen. Erityisesti monet kaupunkiympäristötoimialalla toimivista viranhaltijoista ovat tulleet alalle aikana, jolloin suunnittelijoilla oli mahdollisuus tehdä kaupunkisuunnitteluun ja kaavoitukseen liittyviä päätöksiä suhteellisen itsenäisesti (Puustinen 2006). Tästä syystä suurelta osalta kaupungin suunnittelijoista puuttuu osallistumisen edistämiseen tarvittava koulutus sekä osaaminen esimerkiksi julkisten kuulemisten järjestämiseksi sekä suunnitelmiin annettuihin kommentteihin vastaamiseksi (Leino 2006).

"Lainsäädännön kautta on tullut koko ajan enemmän sitä, että kuntalaisia pitää saada osallistumaan, mutta me ei ole koskaan saatu mitään resursseja, tai koulutusta siihen. Meillä ei ole mitään muuta keinoa siihen, kuin että jokainen valitsee itse sen tavan, minkä hän kokee parhaimmaksi. Kun ei näillä meidän suunnittelijoilla ole osaamista siihen." (VH13)

Suunnittelutyötä tekevien viranhaltijoiden puutteet osaamisessa heijastuvat myös suunnittelijoiden asenteissa sekä suhtautumisessa kuntalaisosallistumista kohtaan. Osa suunnittelijoista ei koe kuntalaisten kuulemista tärkeänä, vaan näkevät sen ylhäältä päin asetettuna ylimääräisenä vaatimuksena, jota he joutuvat toteuttamaan varsinaisen suunnittelutyönsä ohessa (Leino 2006; Puustinen 2006). Suunnittelijoilla ei ole todellista halua kuntalaisten näkemysten kuulemiseksi, vaan kuntalaisosallistuminen saatetaan nähdä jopa uhkana, joka vaarantaa laadukkaan kaavoitus- ja suunnittelutyön toteutumisen. Tästä syystä suunnittelijat näkevät, että kaavoitus- ja suunnittelutyö tulee jättää ennen kaikkea kaavoitukseen ja kaupunkisuunnitteluun perehtyneiden asiantuntijoiden tehtäväksi.
Toisaalta muuttuvat työnkuvat koskevat myös muilla toimialoilla kuin kaupunkiympäristötoimialalla toimivia viranhaltijoita. Kuntalaisosallistumisen roolin kasvamisen myötä viranhaltijoilta odotetaan entistä enemmän valmiuksia kuntalaisten kohtaamiseen. Tämä haastaa perinteisen käsityksen siitä, että viranhaltijoiden näkemyksillä olisi aina automaattisesti enemmän painoarvoa kuin kuntalaisten mielipiteillä. Osa viranomaisista ovat tottuneet muuttuneeseen työkuvaan paremmin kuin muut ja näkevät kuntalaisosallistumisen arvon työssään. Toisille viranhaltijoille kuntalaisten osallistuminen puolestaan tarkoittaa uhkaa omalle asiantuntijuudelle perustuvalla valta-asemalle.

"Hirveän usein viranhaltijoissa näkee sellaista asennetta, että me tiedetään parhaiten, millaisia palveluita kuntalaisilla tulee tarjota. Että tavallaan, kun ihmisillä on se oma asiantuntemus ja koulutus sekä halu tehdä tietynlaisia juttuja, niin se on se suurin este, ettei kuntalaisia kuunnella. Kyllä se varmaan pikkuhiljaa muuttuu, mutta sen eteen täytyy tehdä töitä."(VH5)

Osittain viranhaltijoiden asenteisiin ja suhtautumiseen osallistumista kohtaan vaikuttavat kielteiset kokemukset osallistumisen toteuttamisesta. Esimerkiksi julkiset esittely- ja kuulemistilaisuudet, joissa suunnittelijat esittelevät kuntalaisille ajankohtaisia kaavasuunnitelmia, näyttäytyvät osalle viranhaltijoista vaikeina ja raskaina tilanteina. Usein esiteltäviin suunnitelmiin liittyy hyvin rankkoja kiistoja ja eturistiriitoja, jolloin viranhaltijat joutuvat perustelemaan suunnitelmia kriittisen yleisön edessä. Tällöin tilaisuudet saattavat johtaa vastakkainasetteluun eri osapuolten kesken, jolloin osa kuntalaisten kritiikistä saattaa kohdistua myös suunnitelmien esittelystä vastaaviin viranhaltijoihin. Joskus kielteinen huomio voi mennä henkilökohtaisuuksiin ja heijastua jopa viranhaltijoiden ja kuntalaisten kohtaamisiin vapaa-ajalla.

Osittain julkisten esittelytilaisuuksien haasteet johtuvat niiden toimintalogiikasta, jossa suunnittelijat ja asukkaat asetetaan epätasaarvoiseen asemaan suhteessa toisiinsa. Tämä johtaa usein siihen, että keskustelut kärjistyvät ja kritiikki kohdistuu nimenomaan tilaisuuden 
vetämisestä vastuussa olevaan viranhaltijaan. Erään vastaajan mukaan joskus yksikin kriittinen asukas pystyy toiminnallaan "torpedoimaan" koko tilaisuuden. Lisäksi esittely- ja kuulemistilaisuudet usein järjestetään vasta silloin, kun merkittävä osa käsiteltävistä päätöksistä on jo tehty eikä kuntalaisilla enää ole tosiasiallista mahdollisuutta vaikuttaa kaavoitus- ja suunnittelupäätöksiin. Tällöin tilaisuuden vetämisestä vastaavan viranhaltijan tehtäväksi jää pelkästään perustella ja puolustella jo tehtyjä päätöksiä.

\section{Kulttuuriset valmiudet}

Kulttuuriset valmiudet viittaavat kuntalaisten osallistumista ja vaikuttamista määrittelevään ja ohjaavaan "järkeen". Tällä tarkoitetaan erilaisia hallinnon sisällä vallitsevia käsityksiä oikeista päätöksenteon tavoista ja käytännöistä. Mikäli yhteiskunnassa vallitsevat normit tukevat suoraa kansalaisosallistumista, uudenlaisten demokratiainnovaatioiden sekä osallistumismenetelmien omaksuminen ja vakiinnuttaminen osaksi olemassa olevaa hallinnollista ja poliittista järjestelmää käy helpommin (Curato \& Böker 2016). Osittain osallistumista ohjaavien periaatteiden omaksumiseen vaikuttavat hallinnon toimintaa ohjaavien erilaisten periaatteiden moninaisuus ja päällekkäisyys. Julkiseen hallintoon kohdistuu hyvin erilaisia vaatimuksia, joiden yhteensovittaminen saattaa osoittautua haasteelliseksi julkisessa hallinnossa toimiville viranhaltijoille (Moynihan 2003).

Haastattelut osoittavat, että julkiseen hallintoon kohdistuvat paineet näkyvät myös Turun kaupungissa. Erityisesti osallistumisen toteutumiseen vaikuttavat viime vuosikymmenien aikana levinneet julkisen-yksityisen kumppanuuden periaatteet, joiden johdosta monet aikaisemmin yksinomaan julkisen hallinnon tehtäväksi asetetuista tehtävistä pyritään nykyisin tuottamaan yhteistyössä yritysten, yhteisöjen ja kansalaisten kanssa (Haveri \& Pehk 2008). Kumppanuuksille ja verkostoyhteistyölle perustuva hallinta asettaa rajoja kuntalaisten osallistumismahdollisuuksille erityisesti tilanteissa, joihin liittyy vahvoja yksityisiä intressejä. Tällöin elinkeinoelämän edustajien mielipiteet otetaan yleensä paremmin huomioon, kuin kaupunkilaisten toiveet ja tarpeet.
"Se nyt tuntuu olevan tämän päivän mantra, ettei me voida tehdä yhtään mitään itse, vaan me tarvitaan tietty määrä kumppaneita. Sitten kun me on valittu se kumppani, se kumppani voi sanella mitä tehdään, jolloin kuntalaisille ei jää paljon sanottavaa siihen enää. Se on sen varjopuoli, että kun halutaan niin sanotusti ulkoistaa sitä tekemistä, niin vähemmän kuntalaisilla on mahdollisuus oikeasti vaikuttaa." (VH13)

Kansalaisosallistumisen periaatteiden omaksumista saattavat hidastaa myös hallinnon sisäiset perinteet ja vakiintuneet päätöksenteon tavat. Ne määrittävät, vallitseeko hallinnossa osallistumisen kulttuuri vai tehdäänkö päätökset mieluummin perinteisten tapojen mukaan, jolloin lopullinen vastuu päätöksenteosta säilytetään vaaleilla valittujen poliitikoiden sekä viranhaltijoiden harteilla (Jäske 2019; Jäntti ym. 2017). Uusien kuntalaisosallistumisen muotojen sekä edustuksellisen demokratian periaatteiden osittainen yhteentörmäys heijastuu siinä, kuinka vastaajat kuvailevat suorien osallistumismenetelmien sekä perinteisten edustuksellisuudelle perustuvien toimintatapojen välistä suhdetta. Osa vastaajista näkevät demokratiainnovaatioiden sekä muiden kansalaisosallistumisen muotojen roolin päätöksenteossa suhteellisen vähäisenä. Erityisesti rahankäytössä kuntalaisten suora osallistuminen ei takaa rahojen tehokkainta mahdollista käyttöä, vaan päätösvalta tulee säilyttää vaaleilla valittujen poliitikkojen sekä heidän ohjauksessaan olevien hallinnon viranhaltijoiden vastuulla.

Valtaosa haastatteluihin osallistuneista viranhaltijoista eivät kuitenkaan näe kuntalaisten osallistumista suorana vaihtoehtona edustukselliselle demokratialle, vaan pitää niitä toisiaan vahvistavina tekijöitä. Osallistuvan demokratian toimintamallit täydentävät edustuksellista demokratiaa tuomalla esiin sellaisia asioita, jotka eivät välttämättä edustuksellisen demokratian kanavien kautta pääse esiin. Näin suoraa osallistumista voidaan pitää vastavoimana perinteisen edustuksellisen demokratian toimintamallien ja -tapojen heikkouksille. Se tarjoaa kuntalaisille aidomman kanavan päätöksentekoon, kuin puoluepolitiikan sekä "poliittisten valtapyrkimysten" värittämä edustuksellinen demokratia. 
Haastattelut osoittavat, että hallinnossa vallitsee hyvin erilaisia käsityksiä oikeaoppisista päätöksenteon tavoista sekä käytännöistä. Tämä näkyy muun muassa siinä, että hallinnossa työskentelevillä toimijoilla on erilaisia käsityksiä siitä, missä järjestyksessä päätettävistä asioista tulee tiedottaa kuntalaisille ja päättäjille. Poliitikkojen mielestä heidän tulisi saada tietoa asioista ennen kuntalaisia, jolloin poliitikoilla on mahdollisuus tutustua valmisteltaviin päätöksiin ennen kuin niistä tulee julkisia. Tästä johtuen kuntalaiset saattavat saada tiedon päätettävistä asioista vasta kun ne ovat käyneet läpi poliittisen prosessin, jolloin kuntalaisten tosiasiallinen mahdollisuus vaikuttaa päätettäviin kysymyksiin on jo saattanut kaventua huomattavasti.

Osallistumisen toteutumista rajoittavat myös kulloisetkin voimassa olevat poliittiset valtasuhteet sekä "lehmänkaupat". Tämä kertoo siitä, että osallistumisen vaikutukset voivat olla riippuvaisia päätöksenteon tilanteessa osallisina olevien tahojen ja intressien taustalla vaikuttavista laajemmista poliittisista kytköksistä. Erityisesti mikäli päätettäviin asioihin liittyy vahvoja poliittisia intressejä, joita tukevat vallassa olevien puolueiden edustajat kunnanvaltuustossa ja hallituksessa, ne saattavat edetä hallinnossa ripeästi. Toisaalta hallinnolla on myös mahdollisuus hidastaa tai muulla tavoin heikentää sellaisten aloitteiden toteuttamista, jotka saattavat vaarantaa puolueiden ja niitä tukevien vahvojen tahojen intressejä. (vrt. Smith 2009, 93.)

"Varmaan kuntalaisten heikot vaikuttamismahdollisuudet johtuvat osittain siitä, että on jo päätetty, että mitä halutaan. Tällöin se on sitten vähän kiusallista, jos osoittautuu, että päätökset eivät olekaan sitä, mitä aluksi haluttiin. Osittain poliittinen valtakin voi siihen liittyä. Joskus päätöksiin liittyy poliittisia lehmänkauppoja, jolloin kuntalaisten mielipiteillä ei oikeasti ole kauheasti vaikutusta." (VH8)

\section{JOHTOPÄÄTÖKSET}

\section{Yhteenveto tutkimustuloksista}

Tutkimuksessa tarkasteltiin kuntalaisten osallistumisen merkitystä sekä osallistumisen toteutumista ylimmän virkamiesjohdon näkökulmasta. Tutkimuksen tulokset osoittavat, että kunta- laisosallistumisen merkitys tiedostetaan hyvin johtavien viranhaltijoiden piirissä. Toisaalta osallistumisen käytännön toteutuksessa on heikkouksia, jotka näkyvät muun muassa siinä, kuinka vaihtelevasti osallistuminen toteutuu eri toimialojen sisällä. Kuntalaisten osallistumisella ei useinkaan ole merkittävää suoraa vaikutusta tehtäviin päätöksiin, vaan ensisijaisesti kuntalaisten osallistumista käytetään tiedon keräämiseksi päätöksiin liittyvistä kysymyksistä, jolloin lopullinen valta päätösten tekemisestä säilyy vastuussa olevilla poliitikoilla sekä viranhaltijoilla. Lisäksi osallistumisen nähdään kasautuvan jo ennestään aktiivisille kansalaisille.

Monet tutkimuksen tuloksista tukevat aikaisempien tutkimuksien johtopäätöksiä. Tutkimus osoittaa, että kansalaisosallistumiseen liittyy erilaisia institutionaalisia taustatekijöitä, jotka voivat edistää tai heikentää osallistumisen toteutumista. Osallistumisen toteutumista heikentävät muun muassa puutteet osallistumista säätelevässä lainsäädännössä, organisaation ja viranhaltijoiden valmiuksissa sekä hallinnon sisällä vallitsevassa osallistumisen kulttuurissa. Tiivistelmä erilaisista osallistumisen toteutumiseen vaikuttavista valmiuksista ja niihin liittyvistä tekijöistä on koottu alla olevaan taulukkoon (Taulukko 1).

Tutkimus osoittaa, että vaikka johtavat viranhaltijat suhtautuvat pääsääntöisesti myönteisesti kuntalaisten osallistumiseen, viranhaltijoiden kesken on suuria eroja siinä, millaiseksi he määrittelevät osallistumisen ihanteellisen vaikuttavuuden. Tämän kysymyksen voidaan katsoa olevan yhteydessä laajempaan kysymykseen osallistumismenetelmien sekä edustukselliseen demokratiaan kuuluvien vaikuttamistapojen välisestä suhteesta (Jäntti ym. 2017). Osalle viranhaltijoista kuntalaisosallistumisen muodot edustavat puhtaampaa vaikuttamisen tapaa, kuin edustuksellisen järjestelmän läpi "suodattuvat" vaikuttamistavat. Toiset ovat puolestaan sitä mieltä, että uusien osallistumismenetelmien tehtävänä on ainoastaan täydentää edustukselliselle demokratialle pohjautuvaa päätöksentekoa. Esimerkiksi suuria rahallisia investointeja koskevissa päätöksissä vastaajat pitävät vakiintuneita, edustuksellisuudelle perustuvia toimintatapoja ensisijaisina päätöksentekotapoina.

Tutkimuksen tulokset kertovat käynnissä olevasta ja keskeneräisestä kulttuurisesta muutoksesta, jossa hallinnon sisällä vaikuttaa saman- 
Taulukko 1. Hallinnon valmiudet kansalaisosallistumisen kehittämiseen

\begin{tabular}{|c|c|}
\hline \multicolumn{2}{|l|}{ Hallinnon valmiudet } \\
\hline Lainsäädäntö & Osallistumista koskeva lainsäädäntö eri toimialoilla \\
\hline \multirow{5}{*}{$\begin{array}{l}\text { Organisatoriset } \\
\text { valmiudet }\end{array}$} & Osallistumisen toteuttamiseen käytettävissä olevat taloudelliset resurssit \\
\hline & Tiedonkulku hallinnon sisällä \\
\hline & Toimintojen koordinaatio ja työnjako \\
\hline & Osallistumisen arviointiin käytettävissä olevat työkalut ja käytännöt \\
\hline & Osallistumisen pitkäjänteisyys \\
\hline \multirow[t]{3}{*}{ Yksilölliset valmiudet } & Viranhaltijoiden käytettävissä oleva työaika \\
\hline & Viranhaltijoiden osaaminen \\
\hline & $\begin{array}{l}\text { Viranhaltijoiden asenteet kuntalaisten mielipiteitä ja kuntalaisten osallistumista } \\
\text { kohtaan }\end{array}$ \\
\hline \multirow[t]{2}{*}{ Kulttuuriset valmiudet } & Hallinnon sisäiset päätöksenteon tavat \\
\hline & Päätöksentekoa ohjaavat periaatteet \\
\hline
\end{tabular}

aikaisesti erilaisia näkemyksiä kuntalaisosallistumisen tavoitteista ja tehtävistä. Huomattavaa on, että vaikka viranhaltijoiden kesken tuntuu vallitsevan yleinen käsitys kuntalaisosallistumisen hyödyllisyydestä, viranhaltijoiden käsitykset muiden hallinnon edustajien asenteista ovat kielteisempiä. Vastaajat näkevät, että erityisesti hallinnon alemmalla tasolla viranhaltijoiden asenteet kuntalaisten osallistumista kohtaan ovat osittain vähätteleviä. Tätä voidaan pitää osoituksena siitä, etteivät kuntalaisosallistumista säätelevät strategiat ja mallit ole vielä saaneet jalansijaa kaikilla hallinnon tasoilla. Toisaalta viranhaltijat voivat pyrkiä vierittämään hallinnon ongelmia alemmalla hallinnon tasolla toimivien viranhaltijoiden vastuulle. Tämän on katsottu olevan aikaisemmassa tutkimuksessa ominaispiirteenä erityisesti sellaisissa organisaatioissa, joissa vallitsee samanaikaisesti hyvin erilaisia ja keskenään ristiriitaisia tavoitteita muun muassa päätöksenteon demokraattisuutta sekä tehokkuutta kohtaan (vrt. Pellinen ym. 2018).

\section{Askelmerkkejä tulosten hyödyntämiseen sekä jatkotutkimukselle}

Tutkimuksessa tunnistetut osallistumisen toteutumisen kannalta oleelliset taustatekijät luovat pohjaa hallinnon kehittämiseksi siten, että erilaiset osallistumiskanavat voidaan integroida paremmin osaksi kunnan hallinnollista järjestelmää. Osa taustatekijöistä koskee osallistumista säätelevää lainsäädäntöä, joka säätelee kansalaisosallistumisen edellytyksiä valtakunnallisesti. Tutkimuksen tulokset osoittavat, että viranhaltijat kokevat lainsäädännöstä tulevien velvoitteiden ohjaavan osallistumista vaihtelevasti eri toimialoilla. Mikäli osallistumistyötä koskevan oikeudellisen sääntelyn merkitystä halutaan korostaa, vaatii se konkreettisten velvoitteiden lisäämistä kuntalaisten osallistumista ja vaikuttamista koskevaan lainsäädäntöön. Toisaalta lainsäädännöstä tulevien velvoitteiden tulee myös olla realistisia suhteessa paikallishallinnon resursseihin.

Lisäksi kuntalaisten osallistumista voidaan tukea kuntaorganisaation sisäisiä sekä viranhaltijoiden henkilökohtaisia valmiuksia kehittämällä. Organisatorisia valmiuksia voidaan edistää muun muassa kaupungin osallistumisstrategiaa selkeyttämällä sekä osallistumistavoitteita sekä -tapoja määrittelemällä. Osallistumisen tavoitteiden ja tapojen tulee olla läpileikkaavasti julkituotuna hallinnon ohjaavissa asiakirjoissa ja myös osallistumisen vaikuttavuuden arvioimiseksi tulee olla käytössä toimintatapoja. Osallistumista toteuttavien viranhaltijoiden henkilökohtaisia valmiuksia voidaan puolestaan vahvistaa ohjeistuksella, koulutuksella sekä henkilöstöresursseja lisäämällä. Osallistumisen 
toteutumisen kannalta on tärkeää, että viranhaltijoilla on riittäviä taitoja sekä ajallisia resursseja osallistumisprosessien suunnitteluun ja toteutukseen.

Viimeiseksi, osallistumismahdollisuuksien edistäminen vaatii myös muutoksia hallinnossa vallitsevaan poliittiseen kulttuuriin. Yksilöllisellä tasolla osallistumisen kulttuuria voidaan edistää yksittäisten viranhaltijoiden asenteisiin ja suhtautumiseen vaikuttamalla. Viranhaltijoiden ymmärrystä osallistumisen hyödyistä sekä roolista omassa työssä voidaan vahvistaa tarjoamalla viranhaltijoille ohjeistusta sekä koulutusta. Kollektiivisella tasolla osallistumisen kulttuurin omaksuminen voi vaatia aikaa, jotta osallistumisen periaatteet vakiintuvat osaksi hallinnon toimintaa. Ihanteellisesti osallistuminen on pitkäjänteistä ja tavoitteellista toimintaa, joka ei lakkaa projektirahoituksen loppuessa, vaan tarjoaa kuntalaisille jatkuvan tavan olla mukana kaupungin palveluiden sekä asuinympäristönsä kehittämisessä. Lisäksi osallistumisen edistäminen vaatii tietoista toimintaa erilaisten kuntalaisten osallistumista edistävien normien ja käytäntöjen edistämiseksi ja vakiinnuttamiseksi. Tämä voi edellyttää myös organisaation sisäistä keskustelua hallinnolle asetettujen vaatimusten yhteensovittamisesta sekä eri osallistumistapojen priorisoinnista erilaisissa päätöksenteon kysymyksissä ja vaiheissa (Landwehr 2015; Thompson 2008).

Koska tutkimuksen aineisto on kerätty vain yhdessä kuntaorganisaatiossa, on syytä pohtia, kuinka hyvin tutkimuksen tulokset ovat hyödynnettävissä muissa suomalaisissa kaupungeissa. Viime kädessä kysymys tiivistyy siihen, kuinka tyypillistä suurkaupunkia Turku edustaa ajatellen johdon asenteita ja yleistä ajattelumaa-

\section{LÄHTEET}

Adenskog, Magnus (2018). Democratic Innovations in Political Systems - Towards a Systemic Approach. Örebro Studies in Political Science 42.

Bherer, Laurence (2010). Successful and Unsuccessful Participatory Arrangements: Why Is There a Participatory Movement at the Local Level? Journal of Urban Affairs, 32(3), 287-303.

Blakeley, Georgina (2010). Governing Ourselves: Citizen Participation and Governance in Barcelona and Manchester. International ilmaa. Vaikka Turun erityisyyttä suhteessa muihin Suomen kuntiin ei tämän tutkimuksen puitteissa ole ollut mahdollista selvittää, ei tutkimushaastatteluissa kuitenkaan ilmennyt mitään poikkeuksellisuuteen viittaavaa. Tästä syystä on oletettavaa, että monet tutkimuksessa esiin nousseet ongelmakysymykset uusien osallistumismenetelmien integroimisen haasteista koskevat tällä hetkellä myös monia muita suomalaisia kuntia. Näiden haasteiden ratkaiseminen on tärkeää, kun kunnat pyrkivät edistämään kuntalaisten osallistumis- ja vaikuttamismahdollisuuksia heitä koskevissa päätöksissä.

Huomionarvoista on, että tutkimusta varten haastatellut viranhaltijat edustavat hallinnon ylintä johtoa, jolla ei välttämättä ole käytännön kokemusta osallistumisen toteuttamisesta. Tästä syystä vastaajien näkemykset kuntalaisten osallistumisesta saattavat poiketa varsinaista katutason työtä tekevien viranhaltijoiden näkemyksistä (ks. Tahvilzadeh 2015). Tutkimuksessa ei myöskään ole otettu huomioon kuntalaisten omia käsityksiä osallistumisesta. Kuntalaisten kyvyillä ja taidoilla voi olla yhteys kuntalaisten valmiuksiin ja halukkuuteen käyttää erilaisia osallistumistapoja ja -malleja (ks. Jäske 2019; Lundell ym. 2016). Kuntalaisten osallistumis- ja vaikuttamismahdollisuuksia edistettäessä tuleekin kiinnittää huomiota myös alemmalla hallinnon tasolla työskentelevien viranhaltijoiden sekä kuntalaisten näkökulmiin osallistumista koskien.

Tutkimusta ovat rahoittaneet Strategisen tutkimuksen neuvoston rahoittama Osallistuminen pitkäjänteisessä päätöksenteossa (PALO) -tutkimushanke (312671/312676) sekä Turun kaupunkitutkimusohjelma.

Journal of Urban and Regional Research, 34(1), 130-145.

Blaug, Ricardo (2002). Engineering Democracy. Political Studies, 50, 102-116.

Blaug, Ricardo (2010). How Power Corrupts: Cognition and Democracy in Organisations. New York: Springer.

Borg, Sami (2013). Indikaattorikatsaukset. Teoksessa Borg, Sami (toim.), Demokratiaindikaattorit 2013 (s. 17-94). Helsinki: Oikeusministeriö. 
Bäcklund, Pia \& Kallio, Kirsi-Pauliina (2012). Poliittinen toimijuus julkishallinnon lapsi- ja nuorisopoliittisessa osallistumisretoriikassa. Alue ja Ympäristö, 41(1), 40-53.

Christensen, Henrik S. (2015). Process or Outcome? How the Citizens' Initiative to Ban Fur Farming Affected Political Trust among Users of Avoin Ministeriö. Research on Finnish Society, 8, 61-71.

Christensen, Henrik S., Jäske, Maija, Setälä, Maija \& Laitinen, Elias (2016). Demokraattiset innovaatiot Suomessa - Käyttö ja vaikutukset paikallisella ja valtakunnallisella tasolla. Valtioneuvoston selvitys- ja tutkimustoiminnan julkaisuja nro 56.

Curato, Nicole \& Böker, Marit (2016). Linking mini-publics to the deliberative system: A research agenda. Policy Sciences, 49(2), 173-190.

Dryzek, John S. \& Tucker, Aviezer (2008). Deliberative innovation to different effect: Consensus conferences in Denmark, France, and the United States. Public Administration Review, 68(5), 864-876.

Font, Joan, Sesma, Dolores \& Fontcuberta, Paloma (2014). The causes of local participation. Teoksessa Font, Joan, Della Porta, Donatella \& Sintomer, Yves (Eds.), Participatory democracy in southern Europe. Causes, characteristics and consequences (s. 37-69). Lontoo: Rowman \& Littlefield.

Ganuza, Ernesto \& Baiocchi, Gianpaolo (2012). The Power of Ambiguity: How Participatory Budgeting Travels the Globe. Journal of Public Deliberation, 8(2), artikkeli 8.

Geissel, Brigitte \& Newton, Kenneth (Eds.) (2012). Evaluating Democratic Innovations: Curing the Democratic Malaise? Lontoo ja New York: Routledge.

Haveri, Arto \& Pehk, Teele (2008). Verkostokunta johtamisen ja demokratian haasteena. Tampere: Tampere University Press.

Hendriks, Carolyn (2016). Coupling Citizens and Elites in Deliberative Systems: The Role of Institutional Design. European Journal of Political Research, 55, 43-60.

Häikiö, Liisa (2005). Osallistumisen rajat. Tampere: Tampere University Press.

Häikiö, Liisa, Lehtonen, Pauliina \& Salminen, Jarkko (2016). Globaalin menetelmän paikalliset käytännöt - osallistuva budjetointi Tesomajärven suunnittelussa. Yhdyskuntasuunnittelu, 54(1), artikkeli 2.

Johnson, Genevieve F. (2015). Democratic Illusion. Deliberative Democracy in Canadian Public Policy. University of Toronto Press.
Jäntti, Anni, Airaksinen, Jenni \& Haveri, Arto (2017). Osallistuminen julkishallinnon legitimiteettikysymyksenä. Teoksessa Bäcklund, Pia, Häkli, Jouni \& Schulman, Harry (toim.), Kansalaiset kaupunkia kehittämässä (s. 34-57). Tampere: Tampere University Press.

Jäppinen, Tuula (2013). Käyttäjädemokratia. Teoksessa Piipponen, Sirkka-Liisa ja PekolaSjöblom, Marianne (toim.), Kuntademokratian ja -johtamisen tila valtuustokaudella 2009-2012 (s. 63-68), Helsinki: Kuntaliitto.

Jäske, Maija (2018). Participatory Innovations and Maxi-Publics: The Influence of Participation Possibilities on Perceived Legitimacy at the Local Level in Finland. European Journal of Political Research, 58, 603-630.

Jäske, Maija (2019). Democratic Innovations in Finnish Local Politics: Essays on the Varieties, Causes and Consequences of Mechanisms for Direct Citizen Participation. Turku: University of Turku.

Kuokkanen, Kanerva (2016). Developing Participation through Projects? A Case Study from the Helsinki Metropolitan Area. Helsinki: University of Helsinki.

Landwehr, Claudia (2015). Democratic MetaDeliberation. Political Studies, 63, 38-54.

Leino, Helena (2006). Kansalaisosallistuminen ja kaupunkisuunnittelun dynamiikka: Tutkimus Tampereen Vuoreksesta. Tampere: Tampere University Press.

Lewanski, Rodolfo (2013). Institutionalizing Deliberative Democracy: The 'Tuscany laboratory', Journal of Public Deliberation, 9(1), Article 10.

Lundell, Krister, Karjalainen, Maija \& Christensen, Henrik S. (2016). After the Merger: Do Citizens Want Democratic Innovations? Scandinavian Journal of Public Administration, 20(3), 3-31.

Mansbridge, Jane, Bohman, James, Chambers, Simone, Christiano, Thomas, Fung, Archon, Parkinson, John, Thompson, Dennis F. \& Warren, Mark E. (2012). A systemic approach to deliberative democracy. Teoksessa Parkinson, John \& Mansbridge, Jane (Eds.), Deliberative Systems (1-26). Cambridge: Cambridge University Press.

Matikainen, Janne, Talvitie-Lamberg, Karoliina \& Kunnas, Heikki (2008). Virkamiesten asennoituminen verkko-osallistumista kohtaan. Hallinnon Tutkimus, 27(4), 22-37.

Michels, Ank \& De Graaf, Laurens (2010). Examining Citizen Participation: Local Participatory Policy Making and Democracy. Local Government Studies, 36(4), 477-491. 
Michels, Ank (2011). Innovations in Democratic Governance: How Does Citizen Participation Contribute to a Better Democracy? International Review of Administrative Sciences, 77(2), 275293.

Michels, Ank (2012). Citizen Participation in Local Policy Making: Design and Democracy. International Journal of Public Administration, 35(4), 285-292.

Moynihan, Donald P. (2003). Normative and Instrumental Perspectives on Public Participation: Citizen Summits in Washington, D.C. The American Review of Public Administration, 33(2), 164-188.

Myllyniemi, Sami (2013). Vaikuttava osa. Nuorisobarometri 2013. Nuorisoasiain neuvottelukunnan julkaisuja nro 50.

Nabatchi, Tina \& Amsler, Lisa B. (2014). Direct Public Engagement in Local Government. The American Review of Public Administration, 44(4), 63-88.

Nabatchi, Tina (2010). Deliberative Democracy and Citizenship: In Search of the Efficacy Effect. Journal of Public Deliberation, 6(2), artikkeli 8.

Newton, Kenneth (2012). Curing the democratic malaise with democratic innovations. Teoksessa Geissel, Brigitte \& Newton, Kenneth (Eds.), Evaluating Democratic Innovations: Curing the Democratic Malaise? (s. 3-20). Lontoo ja New York: Routledge.

Niinikoski, Marja-Liisa \& Setälä, Maija (2015). Deliberative Mini-Publics and User-Driven Innovation in the Public Sector: Comparing Underpinnings, Procedures and Outcomes. Collaborative Governance and Public Innovation in Northern Europe, 23-45.

Nivala, Elina \& Ryynänen, Sanna (2013). Kohti sosiaalipedagogista osallisuuden ideaalia. Sosiaalipedagoginen aikakauskirja, vuosikirja 2013, 9-41.

Pekola-Sjöblom, Marianne (2013). Kunnan tarjoamat osallistumis-, vaikuttamis- ja palautetavat. Teoksessa Piipponen, Sirkka-Liisa \& PekolaSjöblom, Marianne (toim.), Kuntademokratian ja -johtamisen tila valtuustokaudella 2009-2012 (s. 44-62). Helsinki: Kuntaliitto.

Pellinen, Jukka, Mättö, Toni, Sippola, Kari \& Rautiainen, Antti (2018). Blame game or dialogue? Financial, professional and democratic accountabilities in a complex health care setting. Accounting, Auditing and Accountability Journal, 31(2), 626-650.
Pihlaja, Ritva \& Sandberg, Siv (2012). Alueellista demokratiaa? Lähidemokratian toimintamallit Suomen kunnissa. Valtiovarainministeriön julkaisuja nro 27.

Puustinen, Sari (2006). Suomalainen kaavoittajaprofessio ja suunnittelun kommunikatiivinen käänne. Vuorovaikutukseen liittyvät ongelmat ja mahdollisuudet suurten kaupunkien kaavoittajien näkökulmasta. Yhdyskuntasuunnittelun tutkimus- ja koulutuskeskuksen julkaisuja A 34.

Ravazzi, Stefania (2017). When a Government Attempts to Institutionalize and Regulate Deliberative Democracy: The How and Why from a Process-Tracing Perspective, Critical Policy Studies, 11(1), 79-100.

Rättilä, Tiina \& Rinne, Jarmo (2017). Ei osallistumista vaan vaikuttamista! Asukasaktiivit paikallisina toimijoina ja asuinympäristön kehittäjinä. Teoksessa Bäcklund, Pia, Häkli, Jouni \& Schulman, Harry (toim.), Kansalaiset kaupunkia kehittämässä (s. 99-117). Tampere: Tampere University Press.

Setälä, Maija (2017). Connecting Deliberative Mini-Publics to Representative Decision Making. European Journal of Political Research, 56, 846-863.

Sintomer, Yves, Herzberg, Carsten \& Röcke, Anja (2008). Participatory Budgeting in Europe: Potentials and Challenges. International Journal of Urban and Regional Research, 32(1), 164-178.

Sjöblom, Stefan (2011). Finland: The Limits of the Unitary Decentralized Model. Teoksessa Loughlin, John, Hendriks, Frank \& Lidström, Anders (Eds.), The Oxford Handbook of Local and Regional Democracy in Europe. Oxford: Oxford University Press.

Smith, Graham (2009). Democratic Innovations: Designing Institutions for Citizen Participation, Cambridge: Cambridge University Press.

Steiner, Jürg (2012). The Foundation of Deliberative Democracy. Empirical Research and Normative Implications. Cambridge: Cambridge University Press.

Tahvilzadeh, Nazem (2015). Understanding Participatory Governance Arrangements in Urban Politics: Idealist and Cynical Perspectives on the Politics of Citizen Dialogues in Göteborg, Sweden. Urban Research \& Practice, 8(2), 238254.

Thompson, Dennis F. (2008). Deliberative Democratic Theory and Empirical Political Science. Annual Review of Political Science, 11(1), 497-520. 